\title{
The Influence of Media Usage on Iranian Students' Pro-Environmental Behaviors: An Application of the Extended Theory of Planned Behavior
}

\author{
Saeid Karimi ${ }^{1, *(\mathbb{D})}$, Genovaitè Liobikienè ${ }^{2} \mathbb{D}$, Heshmatollah Saadi $^{1}$ and Fatemeh Sepahvand $^{1}$ \\ 1 Department of Agricultural Extension and Education, Faculty of Agriculture, Bu-Ali Sina University, \\ Hamedan 65178 33131, Iran; hsaadi48@yahoo.com (H.S.); sepahvandfatemeh1365a@gmail.com (F.S.) \\ 2 Research Institute for Bioeconomy, Vytautas Magnus University, Universiteto St. 10-428, \\ LT-53361 Akademija, Kaunas District, Lithuania; genovaite.liobikiene@vdu.lt \\ * Correspondence: skarimi@basu.ac.ir
}

check for updates

Citation: Karimi, S.; Liobikienè, G.; Saadi, H.; Sepahvand, F. The Influence of Media Usage on Iranian Students' Pro-Environmental Behaviors: An Application of the Extended Theory of Planned Behavior. Sustainability 2021, 13, 8299. https://doi.org/10.3390/su13158299

Academic Editor:

Enrique-Javier Díez-Gutiérrez

Received: 29 June 2021

Accepted: 23 July 2021

Published: 25 July 2021

Publisher's Note: MDPI stays neutral with regard to jurisdictional claims in published maps and institutional affiliations.

Copyright: (c) 2021 by the authors. Licensee MDPI, Basel, Switzerland. This article is an open access article distributed under the terms and conditions of the Creative Commons Attribution (CC BY) license (https:// creativecommons.org/licenses/by/ $4.0 /)$.

\begin{abstract}
The current study attempted to understand factors influencing students' pro-environmental intentions and behaviors in a developing nation, namely Iran. To do so, a theoretical research model was established by adding media use and environmental knowledge into the theory of planned behavior (TPB). Data were collected using a self-administered questionnaire survey from a sample of 327 Iranian students and analyzed with the help of partial least squares structural equation modeling (PLS-SEM). The results supported the applicability of including additional constructs in the TPB, as it has improved the predictive utility of the proposed model. The results indicated that perceived behavioral control, subjective norms, and environmental knowledge were positively associated with pro-environmental intentions. Furthermore, pro-environmental intentions, perceived behavioral control, and environmental knowledge were related to pro-environmental behaviors. Perceived behavioral control and environmental knowledge were also indirectly related to pro-environmental behaviors through pro-environmental intentions. Notably, media use was directly related to proenvironmental behaviors and indirectly related to pro-environmental intentions through perceived behavioral control and environmental knowledge. The theoretical and practical implications of the findings are highlighted.
\end{abstract}

Keywords: pro-environmental behaviors; theory of planned behavior; media use; environmental knowledge; Iran

\section{Introduction}

Increasing environmental destruction and degradation has resulted in numerous environmental health risks, reduction of biodiversity, and climate change [1]. These problems have posed serious challenges and dangers to the planet and its inhabitants, and are a significant threat to society, economy, and natural ecosystems [2]. In this regard, scholars state that people's health and well-being are also related to their natural environment and human actions towards the environment [3]. According to the evidence, Iran has not been safe from these damages and, like many other countries around the globe, the environmental situation in this country is critical and deteriorating. Based on the Environmental Performance Index (EPI) in 2020, Iran is ranked 67th among 180 countries in the world [4]. Environmental problems such as water bankruptcy, deforestation, desertification, loss of biodiversity, air pollution, soil erosion, and many others have become a major concern in this country $[5,6]$, which indicates the insufficiency of the measures taken for the sustainable maintenance and improvement of the environment [4]. Many sociologists believe that these environmental problems are mainly due to environmentally unfriendly behavior [7-10]. Therefore, under these severe conditions, environmental protection strongly depends on stimulating and reinforcing sustainable and pro-environmental 
behavior of individuals [11-15]. Thus, reducing environmental problems and achieving sustainability lies in the study of the determiners of pro-environmental behaviors (PEBs) of individuals $[5,10,16]$. The PEBs of youngsters, especially university students, is of greater importance since they are the ones that have to bear the burden of the neglect of the past and present towards the environment [17]. They are also probably important individuals who acquire the technical and professional knowledge necessary to formulate and present appropriate solutions for changing environmental behavior [18]. According to the literature, the level of environmental awareness and PEBs among Iranian people, including students, is insufficient [19-21]. From an environmental point of view, lack of environmental awareness and behavior among people, especially students who are the future leaders and policymakers, will mean that environmental problems continue unresolved [6]. Therefore, achieving a better understanding of what stimulates them to behave in a more environmentally friendly way is of great importance, since it has practical applications for building a sustainable future $[17,22]$. The development of knowledge is critical for creating strong educational interventions that seek to enhance PEBs $[17,23]$.

Environmental psychological research has emphasized several theoretical frameworks for explaining PEB and its determinants, one of the most prevalent of which is the theory of planned behavior (TPB; [24]). Although many studies in the past have used this theory to explain students' PEB, the majority of these studies have been conducted in developed countries [22,25-27] and very little research has been conducted in developing ones, including Iran. Therefore, the present study identifies the psychological factors affecting the PEBs of Iranian students based on a valid and strong psychological-social model, i.e., the TPB. Moreover, some studies have suggested that more factors of TPB exist that affect pro-environmental intentions and behaviors and are capable of increasing the explanatory power of the theory [28-30]. In fact, the TPB is an open theoretical framework and the extension of the model by adding important variables in a specific context often helps to understand the theoretical mechanisms of the model better and increase the predictive power of the individual's intentions and behaviors in that particular context [24,31]. Environmental knowledge is one of the most potent predictors of PEBs [14,32,33]. It is unlikely for individuals to be consciously careful about environmental issues or intentionally perform pro-environment behaviors if they are not aware of environmental problems [34]. Moreover, many people get their information and knowledge on environmental issues, including climate change, from the media. Mass media provide an important source of educational information for the public and help to improve the knowledge and understanding of people in society about environmental problems [35,36]. Experts believe that governments and educational and non-governmental organizations are capable of disseminating more appropriate information through media in order to improve environmental measures, thereby having a positive influence on the decisions and PEBs of individuals. Increasing empirical evidence also suggests that media use has an important influence on people's attitudes, intentions, and PEBs [37-40]. Therefore, considering the importance and effect of environmental knowledge and media use in environmental protection, especially with regards to students, this study tries to develop a research framework to investigate the relationship between the variables of media use, environmental knowledge, and psychological variables (i.e., attitudes, subjective norms, and perceived behavioral control) and their effects on students' pro-environmental intentions and behaviors, by adding these constructs to the TPB model while expanding the model and increasing its predictive power.

The findings of this study can provide educators, policy makers of sustainable development, and governmental and non-governmental institutions involved with the environment with more insight and understanding of the environmental behaviors of the young generation and help them in developing more effective educational interventions. 


\subsection{Theoretical Framework and Hypotheses Development}

The TPB is one of the most widely used and referenced theories that explains human behavior through a cognitive approach. This theory has been commonly used in different fields in order to formulate and predict behaviors [29,41,42]. A meta-analysis by Overstreet et al. [43] showed the TPB to be one of the most effective models for predicting and explaining intentions and behaviors. Moreover, the TPB has been used to explain environmental behaviors in different fields, including the workplace [44], waste recycling [45,46], green shopping [1], sustainable transportation usage [30,47], and energy conservation $[17,26]$. Many such studies have proven the appropriateness of using the TPB to explain pro-environmental intentions and behaviors [29].

The TPB states that an individual's behavioral intention is affected by three factors, namely attitude, subjective norms, and perceived behavioral control (PBC), and behavioral intention eventually results in the occurrence of actual behavior. Meanwhile, PBC directly and positively affects the actual behavior. Attitude indicates the extent to which the behavior under question is desirable, pleasant, useful, or enjoyable to the person, which depends on the individual's judgement of the effects and consequences of that behavior. Subjective norms refer to the social pressure perceived by the individual to perform or not to perform the behavior in question. In other words, the person's perception of the pressure from important people that he/she should or should not do a specific behavior. PBC, which is similar to self-efficacy [48] in concept, refers to the person's perception of how much control he or she has over performing a specific behavior and the difficulty or ease of performing that behavior. Behavioral intention also refers to the degree of will and desire of a person to perform a specific behavior. According to the TPB, intention is the single best predictor of behavior [19]. Several studies in the field of the environment have also shown that environmental behavioral intention is the most important predictor of PEBs [30,49-51]. A meta-analysis study investigating common theories in environmental psychology has shown that intention is the most powerful predictor of behavior [52]. It should be noted that the roles of attitude, subjective norms, and PBC in predicting intention and behavior are not the same, but rather "depend on the type of behavior and the nature of the situation" [24]. However, in general, the relationships within the TPB model in different areas of environmental behaviors have been proven in various studies $[1,17,26,29,30,53,54]$. For instance, Yazdanpanah and Forouzani [55] suggested that attitude has a positive and significant impact on the intention of Iranian students to buy organic food. A study by de Leeuw et al. [17] on students in Luxembourg showed that attitudes, subjective norms, and PBC significantly affect environmental intentions. That intention, along with PBC, affects PEBs. Yadav and Pathak [53] stated that attitude, subjective norms, and PBC have a significant effect on the intention of Indian students to buy green products. The research conducted by Wang et al. [29] showed that attitude, PBC, and subjective norms influence behavioral intentions positively, while $\mathrm{PBC}$ and behavioral intentions provide a positive impact on PEBs. In addition, meta-analysis studies on various environmental behaviors have shown that attitudes, norms, and $\mathrm{PBC}$ have a positive and significant relation to environmental intentions and that environmental intentions and $\mathrm{PBC}$ have a positive and significant relation with PEBs, as well [52,56]. Thus, the following hypotheses are proposed.

Hypothesis 1 (H1). Environmental attitude is positively related to pro-environmental intentions.

Hypothesis 2 (H2). Subjective norms are positively related to pro-environmental intentions.

Hypothesis 3 (H3). $P B C$ is positively related to pro-environmental intentions.

Hypothesis 4 (H4). PBC is positively related to pro-environmental behaviors.

Hypothesis 5 (H5). Pro-environmental intentions are positively related to pro-environmental behaviors. 


\subsection{Inclusion of Environmental Knowledge in the TPB}

As stated above, new variables can be integrated into the TPB in order to provide a better understanding of individual behaviors. Numerous studies have added new structures into the TPB model $[40,51,53,57]$. Following previous studies, environmental knowledge and the use of media were added to the TPB model in this study in order to improve our understanding of students' pro-environmental intentions and behaviors.

Environmental knowledge, which has received great attention in the literature on environmental behavior, is the cognitive component of environmental awareness [58-61]. Environmental knowledge is the general knowledge of individuals about facts, concepts, and relationships in the natural environment and its main ecosystems [62]. According to Zsoka et al.'s [61] definition, environmental knowledge refers to the knowledge and awareness of environmental issues and problems and their possible solutions. Environmental knowledge refers to "realizing the importance of the environment" [63]. If an individual is unaware of environmental issues, he/she cannot consciously protect the environment or act in a pro-environmental way [34]. Environmental knowledge is one of the most important drivers of environmental behaviors [62]. Vicente-Molina et al. [64] found that environmental knowledge has a positive and significant impact on pro-environmental intentions and behaviors of students, both in developed and developing countries. Furthermore, a study by Yadav and Pathak [53] showed that environmental knowledge has a positive effect on the pro-environmental intentions of students. Studies by Liu et al. [65] and Wang et al. [32] also indicated a positive relationship between environmental knowledge and pro-environmental intentions and behaviors.

It should be noted that environmental knowledge can be divided into two groups of objective and subjective knowledge. Objective knowledge (actual knowledge), which is tested and validated, represents what one actually knows objectively regarding a subject, product, or issue (e.g., the environment) [66]. Objective environmental knowledge refers to precise information regarding the environment stored in a person's long-term memory [64]. On the other hand, subjective knowledge (perceived knowledge) is evaluated or classified by the individual itself and expresses a person's self-evaluation and perception of a subject, issue, or product. In other words, it indicates how much one believes he/she knows about particular environmental issues and actions [67]. Subjective environmental knowledge is used in this study, since previous studies in the literature suggest that this type of knowledge can more effectively predict PEBs compared to objective knowledge $[68,69]$. Based on the discussions above, the following hypotheses were developed:

Hypothesis 6 (H6). Environmental knowledge is positively related to pro-environmental intentions.

Hypothesis 7 (H7). Environmental knowledge is positively related to pro-environmental behaviors.

\subsection{Inclusion of Media Use in the TPB}

Media use generally refers to exposure to the media (i.e., the extent to which a person is faced with specific messages in the media, for example about protecting the environment), or attention to the media (i.e., the extent of intentional attention of individuals to special types of messages from the media, for example about protecting the environment), which includes both traditional media such as television and newspapers, and virtual media such as the Internet and social networks. According to the agenda-setting theory [70], the media affect the knowledge and attitude of people and determine their mental priorities by selecting and highlighting some issues and events in the form of news and reports. In other words, the media play an important role in influencing people's perceptions and directing their thoughts towards a particular issue.

The media also equip people with relevant key scientific information concerning environmental issues and problems such as climate change and environmental protective measures and help change their views and attitudes toward this field. In recent decades, the media has shown increasing interest in reporting on environmental issues and problems. 
These messages mainly emphasize the dangers, problems, and environmental effects on the Earth, people, and animals. People have become increasingly dependent on the media to shape their attitudes and behaviors on environmental issues [71]. It has become clear that mass media have a tremendous effect on public perceptions of environmental problems, including climate change and global warming [72]. These media simplify and make understandable the complex, ambiguous, and abstract information regarding climate science [73]. When people have sufficient knowledge and understanding of the adverse effects of climate change and global warming, they may accept PEBs [74]. Scholars believe that the use of media can facilitate environmentalism [75-77], since it provides people with a sense of reality about natural environments that they may not have directly experienced and enables them to monitor the state of the environment $[39,78]$. These cognitive resources serve as a prelude to increase environmental concerns and initiate environmental protective behaviors $[39,79,80]$. Nelms et al. [81] found that individuals who considered themselves pro-environment were different from their peers in the face of the media, since the media had equipped them with appropriate knowledge and had stimulated their participation in environmental activities and campaigns. Moreover, environmental issues are inherently dependent on society since their risks and effects often involve a wide range of people. Compared to individual issues, people are mainly reliant on the media when faced with these social issues, in order to shape their perceptions and attitudes [82,83]. As a result, the media have become an important medium for people to learn about environmental issues, interpret their dangers, and receive suggestions to guide their behavior [71].

Recent empirical studies have also shown that using traditional and modern media has a positive relation with pro-environmental intentions and behaviors [51,71,84-86]. For example, Ho and Liao [40] found that paying attention to environmental messages in traditional media has a positive relationship with people's intentions towards green shopping and civil environmental interventions. The results of the study by Huang [37] in Taiwan suggested that people's exposure and attention to the media coverage of global warming had a direct positive impact on PEBs. Liao et al. [87] reported that attention to the media has a positive relationship with Singaporeans' pro-environmental intentions. In a cross-national study in 68 countries, Zhang and Zhong [39] showed that the use of information media through traditional and online media has a positive relationship with people's willingness to pay for environmental protection and their engagement with environmental activities. The study of Shah et al. [36] among Chinese students concluded that the extent of social networks usage and exposure to climate change information on these sites has a positive relationship with the students' PEBs. Liu et al. [65] also reported using the Internet to have a positive relation with PEBs. Thus, the below hypotheses were proposed.

Hypothesis 8 (H8). Media use is positively related to pro-environmental intentions.

Hypothesis 9 (H9). Media use is positively related to pro-environmental behaviors.

\subsection{Media Use and the TPB Constructs}

In general, it can be stated that the use of media and exposure to environment protection messages and information regarding environmental problems can help improve people's intentions and PEBs although few studies have investigated the relationship between the use of media and constructs of the TPB model (i.e., attitudes, subjective norms, and PBC) $[87,88]$. Considering the results obtained from these few studies, one can expect the media to affect these constructs as well. Holbert et al. [89] reported the use of news media to have a positive effect on people's attitudes. A study conducted by Lee [79] among Hong Kong students showed that individuals exposed to environmental messages tend to consider environment-based values (such as biosphere values) as important. Thus, their attitudes towards environment protection are improved by these values. Chan's study [90] on Hong Kong households showed that mass media had a significant impact on residents' subjective norms. In a study among Singapore citizens, Liao et al. [87] found that attention 
to media has a positive and significant effect on subjective norms, attitudes towards the environment, and pro-environmental behavioral intentions. The result of a recent study among Malaysians demonstrated that the mass media affect the knowledge and attitude of people with respect to climate change. This study also showed that the mass media indirectly affect individuals' PEBs by changing their attitudes [88]. To the best of our knowledge, the relationship between media use and $\mathrm{PBC}$ has not been investigated in the literature; however, it can be assumed that when people receive more information about environmental protection and climate change from the media, they will have a higher level of self-efficacy and confidence in performing environmental actions and behaviors. Thus, the following hypotheses were proposed:

Hypothesis 10 (H10). Media use is positively related to attitude towards pro-environmental behaviors.

Hypothesis 11 (H11). Media use is positively related to subjective norms.

Hypothesis 12 (H12). Media use is positively related to PBC.

\subsection{Media Use and Environmental Knowledge}

According to previous studies, the media, especially new media such as the Internet, play an essential role in disseminating and increasing the environmental knowledge of the younger generation [91]. Morgan [92] states that the media are an important source of environmental information for people. According to him, media are the main source of environmental knowledge. Most of what people know about environmental issues such as the greenhouse effect, climate change, ozone depletion, water and air pollution, and other environmental threats is likely to come from the media. Preliminary studies have shown that environmental coverage in traditional media such as television, radio, and newspapers helps to increase environmental awareness and knowledge among the people of different communities [93,94]. Zhao [95] reported that the use of media such as television, newspapers, and the Internet helps to improve people's knowledge about global warming. In recent years, the role of new media, such as the Internet, in improving people's environmental knowledge has become more prominent. Burton et al. [96] found that many individuals have received their ecological knowledge through the Internet since 2000. Recent studies have also shown that the use of social media within the Internet has provided important advantages in improving environmental awareness and knowledge [97]. Li's study [86] suggested a positive relationship between the use of traditional and modern media and individuals' environmental knowledge. In addition, the study conducted by Liu et al. [65] suggested that the use of the Internet has a significant impact on increasing people's environmental knowledge. Thus, the following hypothesis was proposed:

\section{Hypothesis 13 (H13). Media use is positively related to environmental knowledge.}

Some studies have also investigated the indirect effect of media use on intention and PEBs through cognitive mediators such as environmental knowledge, subjective norms, and PBC [86,87,98]. For instance, Liu et al. [65] concluded that Internet use not only directly affects PEBs but also indirectly influences PEBs through the mediating effects of environmental knowledge. It is also common to examine the mediator effects in predicting the PEBs within the TPB framework [99,100]. For example, Bamberg and Möser [56] proved in a meta-analysis study that environmental intentions would mediate the effects of psychosocial variables on PEBs. Thus, it is also assumed in the present study that pro-environmental intentions mediate the relationship between media use and attitude, subjective norms, PBC, environmental knowledge, and media use. Furthermore, attitudes, subjective norms, PBC, and environmental knowledge mediate the relationship between media use and pro-environmental intentions. 
Based on the above discussion, a comprehensive model was developed to examine the hypothetical relationships, by adding media use and environmental knowledge to the TPB model (Figure 1).

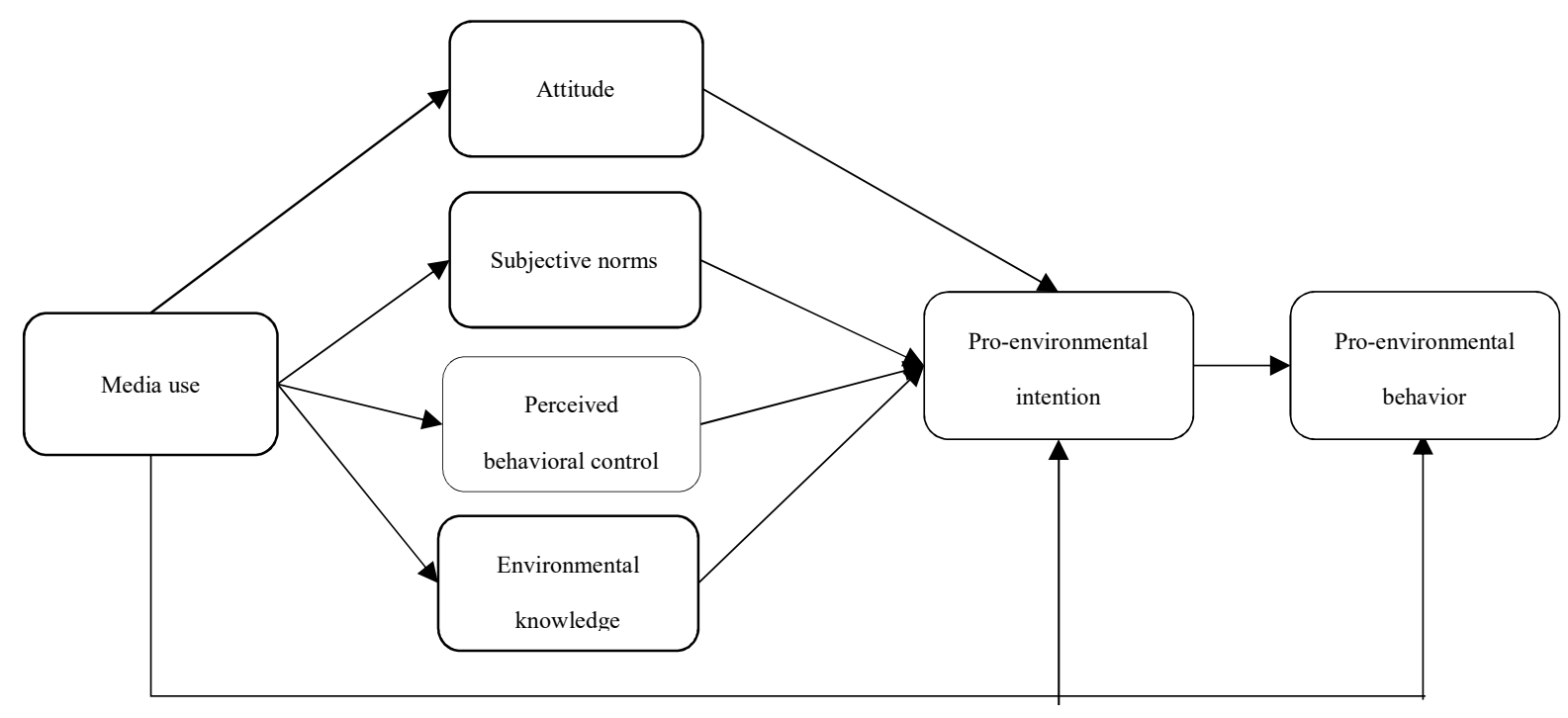

Figure 1. Research model.

\section{Materials and Methods}

\subsection{Sample and Data Collection}

This study was a cross-sectional survey. The data were collected in March 2021 through a web-based survey. Participants in this study included undergraduate and graduate agriculture students in four public universities in western Iran. The questionnaire was designed electronically and a link to the questionnaire was sent to the students with the help and coordination of professors. Filling out the questionnaires was voluntary. Of the 450 students invited to participate in the study, 327 individuals completed the task, making the response rate equal to $73 \%$.

This study followed the 10 times rule of Hair et al. [101] to achieve an estimation of the sample size, which is "10 times the largest number of structural paths directed at a particular latent construct in a structural model". Moreover, the G-Power software (version 3.1) was used to determine the appropriate sample size [102]. The required sample size for the case with an effect size $\left(f^{2}\right)$ of 0.15 , an alpha equal to 0.05 , a power of 0.95 , and the number of independent or predictive variables equal to 6 will be equal to 146 . Moreover, Rinatz et al. proposed a minimum sample size of 100 when using PLS-SEM [103]. Therefore, a sample size of 327 seems sufficient.

The findings showed that about $73 \%$ of all the respondents were female and the rest were male $(27 \%)$. There were more females in the sample because more females were enrolled in the degree programs than males and about $60 \%$ of the Iranian university population in general is female [42].

Regarding the age distribution of students, the majority of them $(73 \%)$ were $20-25$ years old and their average age was 24.60 years. About $80 \%$ of them lived in cities, and the average number of their family members was equal to 4.80 . In terms of parents education, $63 \%$ of their fathers and $66 \%$ of their mothers had a diploma or under diploma degrees and the rest had an academic degree. 


\subsection{Measures}

All items used in the questionnaire were taken from previous research and changed and modified according to the research topic. Since the acquired items were in English, a mutual translational method was used to modify the measurement scale. First, one of the researchers translated the original items from English to Persian. Then, the Persian items were retranslated to English by another researcher. Afterwards, two researchers compared the English version of the questionnaire with the Persian one. After compilation of the initial version of the questionnaire, a number of university professors were invited to examine the face validity of the measurement scales. The wordings of some items were then modified based on their comments and suggestions. Finally, in order to evaluate the reliability of each scale, a pilot study was conducted with 20 students who were not part of the statistical population. Considering their opinions, a number of new changes were made in the wordings, layout, and instructions to further improve the quality and comprehensibility of the questionnaire.

Seven variables, namely media use, environmental knowledge, attitude, PBC, subjective norms, pro-environmental intentions, and PEBs were investigated in this study. To evaluate media use, the respondents were first asked how often they encounter environmental messages and news regarding climate change in mass media, including television, radio, newspapers, journals and magazines, the Internet, and social networks $(1=$ never, and $4=$ always). They were then asked how much they paid attention to the environmental messages and news regarding climate change presented in these media $(1=$ very low, $4=$ very high). Finally, to evaluate media use, the exposure and attention variables were combined for each type of media [37].

In this study, a five-item scale was used to measure environmental attitudes, a six-item scale was used to assess PBC, and a three-item scale was used to evaluate subjective norms, which were all selected according to previous studies [5,17,54,104,105]. A five-point Likert scale was used to evaluate these concepts ("strongly agree" to "strongly disagree").

Five items were used to measure pro-environmental intentions $[15,79,106]$. The participants were asked to declare their level of agreement with each of the behavioral intention items on a five-level scale ("strongly agree" to "strongly disagree").

PEBs were evaluated using 20 items. Their measurement was performed based on the Likert scale from never (0) to always (4). These items were obtained from the Student Environmental Behavior Scale (SEBS) [107] and other previous studies available in the literature [108-110]. Higher average scores indicate that the respondents perform more environmentally responsible actions.

Following previous studies, a five-item scale was also used to measure the subjective environmental knowledge of the participants $[53,68,111,112]$. This scale was also examined on a five-level Likert scale ("strongly agree" to "strongly disagree").

\subsection{Data Analysis}

In this study, the partial least squares structural equation modeling (PLS-SEM) technique was used to analyze the data using SmartPLS 3.3 [113]. Among the benefits of this technique are high prediction accuracy, less sensitivity to normality issues, and the ability to work with complex relationships among constructs $[114,115]$. The use of PLS-SEM is also proposed when research seeks to theoretically expand proven theories [102]. As a result, the use of this technique was totally appropriate for this study. The measurement and structural models were evaluated using a two-stage analysis approach [116].

\section{Results}

About $78 \%$ of the participants stated that they have never participated in environment protection activities, associations, or groups, and only $12 \%$ of them were members in environmental associations or organizations. The findings showed that about $48 \%$ of the participants sometimes discussed environmental issues with their family members. In the 
sample, $69 \%$ of the respondents stated that they occasionally or often watch the news and programs regarding environmental problems such as climate change on television.

About $60 \%$ occasionally or often read these messages on the Internet or social networks. In comparison, only $21 \%$ stated that they sometimes or often listen to environmental messages or programs on the radio. The average level of attention to environmental messages and news was 3.8 for the Internet, 3.76 for social networks, 3.41 for the television, 2.57 for magazines, publications, and books, 2.09 for newspapers, and 2.08 for the radio. The results showed that the Internet and social networks are the main media for receiving information regarding environmental issues and problems such as global warming, followed by television, magazines, publications and books, newspapers, and radio.

\subsection{Measurement Model Assessment}

Convergent and divergent validity and internal reliability were used to evaluate the measurement model. Reliability was assessed using Cronbach's alpha and combined reliability. According to Table 1, the values of Cronbach's alpha and combined reliability were above the proposed value of 0.7 for all constructs, which indicates the acceptable reliability of the constructs. According to Hair et al. [101], the general rule of thumb to achieve a convergent validity is that the factor loads must be greater than 0.7 and the mean variance extracted must be greater than 0.5 . As shown in Table 1, factor loadings exceeded the 0.7 thresholds for all items. Furthermore, AVE values for all constructs (except environmental behaviors) were in the range of $0.51-0.74$. Thus, it can be concluded that all constructs have acceptable divergent validity. The divergent validity was evaluated using the HTMT criterion. The HTMT value between two structures must be less than 0.85 [117]. As stated in Table 2, the measurement model had an acceptable level of divergent validity.

Table 1. Cronbach's alpha, $C R, A V E, R^{2}$, and $Q^{2}$ values.

\begin{tabular}{cccccc}
\hline Variable & A & CR & AVE & $\mathbf{R}^{2}$ & $\mathbf{Q}^{2}$ \\
\hline Pro-environmental behavior & 0.85 & 0.89 & 0.40 & 0.45 & 0.17 \\
\hline Pro-environmental intention & 0.91 & 0.94 & 0.74 & 0.55 & 0.40 \\
\hline Attitude & 0.89 & 0.91 & 0.67 & 0.01 & 0.01 \\
\hline Subjective norms & 0.87 & 0.91 & 0.71 & 0.06 & 0.04 \\
\hline Perceived behavioral control & 0.85 & 0.89 & 0.57 & 0.05 & 0.03 \\
\hline Environmental knowledge & 0.90 & 0.93 & 0.72 & 0.07 & 0.05 \\
\hline Media use & 0.81 & 0.86 & 0.51 & - & -
\end{tabular}

Note: $\alpha$ : Cronbach's alpha; AVE: average variance extracted; CR: composite reliability; $\mathrm{Q}^{2}$ : predictive relevance, $\mathrm{R}^{2}$ : coefficient of determination.

Table 2. Ratio heterotrait-monotrait (HTMT).

\begin{tabular}{ccccccc}
\hline Variables & $\mathbf{1}$ & $\mathbf{2}$ & $\mathbf{3}$ & $\mathbf{4}$ & $\mathbf{5}$ & $\mathbf{6}$ \\
\hline 1-Pro-environmental behavior & - & - & - & - & - & - \\
\hline 2-Pro-environmental intention & 0.57 & - & - & - & - & - \\
\hline 3-Attitude & 0.41 & 0.40 & - & - & - & - \\
\hline 4-Subjective norms & 0.50 & 0.65 & 0.49 & - & - & - \\
\hline 5-Perceived behavioral control & 0.53 & 0.73 & 0.51 & 0.80 & - & - \\
\hline 6-Environmental knowledge & 0.53 & 0.74 & 0.35 & 0.64 & 0.76 & - \\
\hline 7-Media use & 0.60 & 0.32 & 0.12 & 0.30 & 0.25 & 0.30 \\
\hline
\end{tabular}




\subsection{Structural Model Assessment}

The issue of multicollinearity was evaluated following the evaluation procedure for the structural model proposed by Hair et al. [101] All the variance inflation factor (VIF) values for the endogenous variables were lower than the proposed value of 5 , which indicates that there was no sign of multicollinearity issue. Then, the fit of the model was evaluated by assessing the standardized root mean square residual (SRMR) [118]. Since the SRMR value was less than 0.07 for this research model, less than the threshold value of 0.08 , it can be concluded that the model had an acceptable fit.

In the next step, the coefficient for determination $\left(R^{2}\right)$ of endogenous constructs was investigated. In behavioral science research, the values of $0.60,0.33$, and 0.19 are considered strong, average, and weak, respectively [119]. In this study, the $\mathrm{R}^{2}$ value was 0.45 for PEBs, which is above the average value and indicates that 45 percent of the PEBs variance is explained by $\mathrm{PBC}$, media use, intentions, and environmental knowledge. Moreover, the $\mathrm{R}^{2}$ value for pro-environmental intentions was 0.55 , which is above the average level and indicates that $55 \%$ of the pro-environmental intention variance is explained by attitudes, subjective norms, $\mathrm{PBC}$, media use, and environmental knowledge. The model's predictive relevance was also evaluated using the Stone-Geisser criterion $\left(Q^{2}\right)$ [101]. As shown in Table 1 , the $Q^{2}$ values for pro-environmental behaviors and intentions were 0.17 and 0.40 , respectively. Since both values were above zero, the research model was considered to have predictive relevance.

To evaluate the significance of the coefficients for each proposed path in the research model, the bootstrapping technique was performed with 5000 re-samples [101]. The results in Table 3 show that subjective norms and PBC had a significant positive relationship with pro-environmental behavioral intentions. Moreover, $\mathrm{PBC}$ and pro-environmental behavioral intention had a positive significant relationship with PEBs. Therefore, Hypotheses 2, 3, 4, and 5 are approved. However, the relationship between attitudes and pro-environmental behavioral intention was not significant. Therefore, Hypothesis 1 is not approved. The results of structural equations modeling showed that environmental knowledge has a positive and significant relationship with pro-environmental intentions and PEBs, thus approving Hypotheses 6 and 7. Furthermore, the results show that media use has positive significant relationships with subjective norms, $\mathrm{PBC}$, pro-environmental intentions, and PEBs. However, attitude was not significantly related to pro-environmental intentions. Therefore, Hypotheses 8, 9, 11, and 12 are confirmed, while Hypothesis 10 is not approved.

According to Zhao [120], if the indirect effects are significant at a level of $5 \%$ and the confidence interval does not include a value of zero, according to bootstrapping results, the mediating effect will be supported. As shown in Table 3, the specific indirect effects of media use on pro-environmental intentions through $\mathrm{PBC}$ and environmental knowledge are significant at a level of 0.05 . The confidence interval also does not include the value of zero. Additionally, the indirect effects of PBC and environmental knowledge on PEBs through pro-environmental intentions are significant at a level of 0.05 , while the confidence interval did not include the value of zero. However, other indirect effects are not significant at a level of 0.05 .

The study of total effects also showed that environmental knowledge, media use, and PBC have the highest effect on pro-environmental intentions, in that order. Moreover, media use, pro-environmental intentions, and environmental knowledge have the highest effects on PEBs, in that order. 
Table 3. Direct, indirect, and total effects of the research model.

\begin{tabular}{|c|c|c|c|}
\hline Hypotheses & B & t Value & Result \\
\hline \multicolumn{4}{|c|}{ Direct effect } \\
\hline Attitude $\rightarrow$ Intentions & 0.08 & 1.88 & H1: Not supported \\
\hline Subjective norms $\rightarrow$ Intentions & $0.13 *$ & 2.19 & H2: Supported \\
\hline $\mathrm{PBC} \rightarrow$ Intentions & $0.25 * *$ & 3.25 & H3: Supported \\
\hline $\mathrm{PBC} \rightarrow \mathrm{PEB}$ & $0.14^{*}$ & 2.07 & H4: Supported \\
\hline Intentions $\rightarrow$ PEB & $0.23 * *$ & 3.64 & H5: Supported \\
\hline Environmental knowledge $\rightarrow$ Intentions & $0.38^{* *}$ & 5.47 & H6: Supported \\
\hline Environmental knowledge $\rightarrow$ PEB & $0.13 *$ & 1.96 & H7: Supported \\
\hline Media use $\rightarrow$ Intentions & 0.08 & 1.89 & H8: Not supported \\
\hline Media use $\rightarrow$ PEB & $0.40 * *$ & 8.03 & H9: Supported \\
\hline Media use $\rightarrow$ Attitude & 0.10 & 1.56 & H10: Not supported \\
\hline Media use $\rightarrow$ Subjective norms & $0.25^{* *}$ & 4.31 & H11: Supported \\
\hline Media use $\rightarrow$ PBC & $0.21 * *$ & 3.81 & H12: Supported \\
\hline Media use $\rightarrow$ Environmental knowledge & $0.26 * *$ & 4.77 & H13: Supported \\
\hline \multicolumn{4}{|c|}{ Indirect effect } \\
\hline Media use $\rightarrow$ Attitude $\rightarrow$ Intentions & 0.01 & 1.05 & $0.00-0.03$ \\
\hline Media use $\rightarrow$ Subjective norms $\rightarrow$ Intentions & 0.03 & 1.77 & $0.00-0.07$ \\
\hline Media use $\rightarrow$ PBC $\rightarrow$ Intentions & $0.05 *$ & 2.52 & $0.02-0.10$ \\
\hline Media use $\rightarrow$ Environmental knowledge $\rightarrow$ Intentions & $0.10 * *$ & 3.86 & $0.05-0.15$ \\
\hline Media use $\rightarrow$ Environmental knowledge $\rightarrow$ PEB & 0.03 & 1.71 & $0.00-0.07$ \\
\hline Media use $\rightarrow$ Intentions $\rightarrow$ PEB & 0.02 & 1.57 & $0.00-0.05$ \\
\hline Media use $\rightarrow$ PBC $\rightarrow$ PEB & 0.03 & 1.86 & $0.00-0.07$ \\
\hline Subjective norms $\rightarrow$ Intentions $\rightarrow$ PEB & 0.03 & 1.80 & $0.00-0.07$ \\
\hline PBC $\rightarrow$ Intentions $\rightarrow$ PEB & $0.06 *$ & 2.29 & $0.02-11$ \\
\hline Environmental knowledge $\rightarrow$ Intentions $\rightarrow$ PEB & $0.09 * *$ & 2.72 & $0.04-0.16$ \\
\hline \multicolumn{4}{|c|}{ Total effect } \\
\hline Media use $\rightarrow$ Intentions & $0.28 * *$ & 4.70 & - \\
\hline Media use $\rightarrow$ PEB & $0.53 * *$ & 11.14 & - \\
\hline Attitude $\rightarrow$ PEB & 0.02 & 1.35 & - \\
\hline Subjective norms $\rightarrow$ PEB & 0.03 & 1.80 & - \\
\hline $\mathrm{PBC} \rightarrow \mathrm{PEB}$ & $0.19 * *$ & 2.98 & - \\
\hline Environmental knowledge $\rightarrow$ PEB & $0.22 * *$ & 3.46 & - \\
\hline
\end{tabular}
${ }^{*}: p \leq 0.05 ; * *: p \leq 0.01$.

\section{Discussions}

This paper attempted to integrate media use and environmental knowledge within the TPB model in order to identify key drivers of pro-environmental intentions and behaviors among Iranian agriculture students.

The results showed that the two antecedents of the TPB model (i.e., subjective norms and $\mathrm{PBC}$ ) had a positive and significant effect on pro-environmental intentions, which supported the findings of previous studies $[17,30,53]$. Moreover, pro-environmental intentions had a positive and significant effect on PEBs, which is line with the results from previous studies $[14,29]$. In general, the findings supported the application of the TPB in the field of environmental behaviors in a developing country such as Iran. The results also support the inclusion of environmental knowledge and media use in the TPB model. The results showed that in the extended TPB model, the values of intentions and PEBs were 0.55 and 0.45 , respectively, which were greater than the values of 0.46 and 0.29 observed in the original TPB model. Therefore, it can be stated that the extended TPB model has a higher prediction power for predicting the pro-environmental intentions and PEBs of the students, compared to the original model. Among the TPB constructs, environmental attitude did not have a significant relationship with pro-environmental intentions, which differs from the results of most studies conducted in both developed [15] and developing countries [29,53]. This issue indicates that students' positive attitude towards protecting their environment and performing PEBs does not necessarily result in their pro-environmental intentions. Rather, as shown by the results, other factors, such as environmental knowledge and media 
use, may play a more prominent role than environmental attitudes. It should be noted that some research in the past, e.g., [100], has also reported a non-significant relationship between attitudes and intentions of environmental behavior.

Many of the previous studies using the TPB to investigate environmental intentions recognized $\mathrm{PBC}$ as one of the important factors in predicting pro-environmental intentions $[55,121,122]$. In this study, among the TPB constructs, PBC had the strongest effect on pro-environmental intentions. This indicates that students' pro-environmental behavior will be higher if they have confidence and belief in their abilities and control over environmental actions and behaviors. According to the TPB theory, when one imagines that a particular behavior is within their power and confidence, it will activate a sense of preparedness to perform that behavior [24].

The effect of subjective norms on different environmental behaviors has been mixed in previous studies. This study showed that subjective norms have a positive and significant effect on pro-environmental intentions, which is consistent with the results obtained from some previous studies $[17,29,53]$. In this regard, one study [51] stated that subjective norms produce a significant effect on students' environmental behaviors since they are somewhat dependent on their parents and follow or obey social rules based on filial piety and their behaviors are subject to change due to social influences.

The results showed that among the research variables, environmental knowledge has the highest direct effect on students' pro-environmental intentions. Moreover, environmental knowledge affected students' PEBs not only directly but also indirectly through pro-environmental intentions. This finding means that it would be more probable for people who think they have better knowledge and understanding of environmental issues and problems to adopt and perform environmentalist behaviors [123]. The existence of environmental knowledge among the members of society helps them to have a more comprehensive understanding of environmental issues and problems and to assume higher importance for the protection of the environment. These findings are supported by previous studies $[32,53,64,65]$. It should be noted that the level of perceived environmental knowledge among students is relatively low (mean value of environmental knowledge $=3.84 / 5$ ), which justifies the importance of creating knowledge and awareness regarding the environment in developing societies, especially among students.

Unlike previous studies which have mostly focused on the direct effect of the media on PEBs, the present article develops a comprehensive framework for studying the mechanism of action at a deeper level. The results, in line with previous studies, showed that media use has positive direct and indirect effects on the intentions and PEBs of the audience $[37,72,85,87]$. In recent years, the media, especially modern media, have been used continuously to inform and report environmental issues and problems to people. Therefore, it is not surprising that the use of media has a significant impact on individuals' intentions and PEBs. Media use helps the audience to obtain information about environmental issues, and based on this information, they can decide to behave in an environmentally friendly manner and take steps towards protecting the environment $[65,85]$. The more people read or watch about environmental issues, the more likely they will be to get engaged with environmental activities [37,77]. In line with previous studies, the results showed that media use has a positive impact on environmental knowledge [96,97]. The results also showed that environmental knowledge plays an important mediating role between media use, intentions, and PEBs. In other words, media use not only affects PEBs directly, but also affects intentions and PEBs indirectly through environmental knowledge. The media are an important source of information on environmental issues. As a result, media use can improve students' environmental knowledge and thus increase their willingness to engage in environmental behaviors. In particular, social networks can encourage environmental behaviors by encouraging participation in the process of information exchange and knowledge formation [65,124]. Moreover, as suggested by the results, media use has a positive effect on subjective norms and PBC. In other words, those who use the media more are more likely to feel more responsibility for protecting the environment, feel higher 
social pressure to protect the environment, and have more confidence in their ability to take environmental actions. These results are also in line with previous studies [87,88]. However, media use did not produce a significant impact on students' attitudes. One possible reason for this may be the inappropriate selection of supportive messages and discussions in the media that were unable to provide sufficient persuasion.

In addition, the results showed that the use of media provides an indirect positive effect on behavioral intentions through PBC. These results extend the previous research which examined the relationship between media use and environmental behaviors, but failed to explain this process using theoretical perspectives [71]. In particular, this TPBbased study found that the use of media through PBC provides a positive effect on the environmental intentions of students. This means that students who have used media, traditional or modern, to obtain more environmental information are more likely to have higher confidence in their abilities to perform environmental actions, and that this belief will eventually transform into their behavioral intention in protecting the environment. The few studies conducted also suggest that the media provide a positive effect on individuals environmental intentions through psychological variables $[87,88]$. Furthermore, according to the results, media use affects students' environmental intentions positively using environmental knowledge and this indirect effect was even higher than their direct effect (direct effect $=0.08$, indirect effect $=0.10$ ). Overall, the findings of this study showed that the use of media has an important role in developing the pro-environmental intentions and PEBs of Iranian students and has helped them to relate environment protection with their personal beliefs and to improve their environmental knowledge, which will eventually increase their pro-environmental intentions and PEBs.

\section{Implications}

This study has several theoretical implications. Most previous studies on different types of PEBs were conducted in developed countries and it is necessary to study this issue in developing countries $[122,125,126]$. The present study supported the practicality of the ingrained socio-psychological model, i.e., the TPB and its extension in determining pro-environmental intentions and PEBs in a developing country context, namely Iran [84]. Incorporating environmental knowledge and media use within the TPB, this study has improved the robustness and predictive ability of this model in terms of environmental intentions and behaviors. It thus contributes to the existing theory as well. It also helps to understand the impacts of media on students' environmental behaviors. Very few studies have been conducted in this area, especially in developing countries, including Iran. This study helps to expand the literature in this field by investigating the direct and indirect impacts of the media in the formation of pro-environmental intentions and behaviors in a validated theoretical framework, i.e., the TPB. A wide range of different types of traditional and modern media, such as radio, television, newspapers, the Internet, and social networks, was investigated in this research. Therefore, it can better explain how different media affect the environmental intentions and behaviors of students. Although the TPB constructs are proximal antecedents to behavioral intentions, understanding how these factors are developed in relation to environmental behaviors seems necessary [50]. This study provides useful information regarding the role of the media in developing subjective norms, PBC, knowledge, intentions, and PEBs.

The findings of this research provide insights for planners and policy makers to make effective decisions and design appropriate strategies to develop and improve environmental behaviors among different social groups, especially students. Given the direct and indirect effects of PBC on intentions and PEBs, assigning economic and social incentives to improve the sense of self-efficacy in individuals may help in increasing the probability of environmental behaviors. Given the important role of the media in improving knowledge, subjective norms, $\mathrm{PBC}$, intentions, and PEBs, policy makers and planners can use the media to motivate students' environmental motivations and behaviors. Given the effect of the media on subjective norms, communication experts have to focus on improving the envi- 
ronmental attitudes and beliefs of students' reference groups, such as parents and friends. They can emphasize the prevalence of environmental behaviors in the society and improve the perceptions of social expectations towards this desirable behavior. For instance, media's environmental messages can emphasize that many people are recycling materials, using low-consumption appliances, or saving water and electricity. Such messages can foster people's understandings and beliefs that environmental behaviors are prevalent and widely accepted by society and reference groups. Policymakers and members of the media can benefit from performing environmental behaviors and actions as a social trend such as an advertising campaign to demonstrate the popularity of such behaviors. A famous person is a source of social influence and the advertising messages from trusted experts and celebrities can be motivating for people [127]. The media can benefit from this factor. For example, an environmental message stated by celebrities can provide a good social impact. Mass media, along with families and educational institutions, have a key role in expressing the importance of environmental issues and educating people. As also shown by the findings of this study, students' most important source of environmental news is television followed by radio; therefore, environmental issues can be raised through these two media. Along with the media, pro-environmental groups play an important role in attracting public opinion and stating environmental problems. As Rutsaert et al. [128] suggest, social media and networks provide a unique opportunity in providing instant, up-to-date information with the ability of two-way communication. These networks are an appropriate foundation that can be used to improve people's values, knowledge, and attitudes.

Given the positive and important role of environmental knowledge in improving environmental intentions and behaviors, in addition to the use of media to improve environmental knowledge, universities, especially agriculture departments, should try to enhance this type of knowledge in their students. Research shows that participation in environmental educations can have a great impact on the environmental knowledge and awareness of individuals [61,129]. Therefore, it is suggested that universities and educational institutions help improve the environmental knowledge of their students and enhance their awareness and insight into environmental protection by holding appropriate academic courses in order to increase PEBs among students.

\section{Limitations}

This study also faced some limitations. First, the non-probabilistic nature of the sampling technique in this study limits the generalizability of the results. Second, this research was based on a self-report survey in which the responses provided by the participants may be subject to social desirability bias, i.e., the respondents prefer to "look good" on behaviors and actions such as environmental behaviors, whose social desirability is relatively high. This is especially likely among the educated young generation [130]. Third, although accurate and robust statistical tests such as SEM were used in this study, the study was cross-sectional research wherein the causal order of research variables cannot be determined. Future studies should consider the use of longitudinal or empirical designs to map the effects of media on intentions and PEBs. Fourth, there was no detailed information in this study about the media content people are exposed to. Since only the general use of people from the media for environmental information has been investigated, specific forms of content that people consume in different media cannot be discussed. Linking media content and messages, especially to communication effects, will be valuable for theory generation and designing future research. Fifth, in this study, only subjective knowledge was used to analyze students' environmental knowledge, while experts suggest that it is better to use both subjective and objective knowledge to measure environmental knowledge $[131,132]$. Therefore, future studies can use both types of knowledge to measure environmental knowledge. Sixth, in this study, the data were obtained only from agriculture students. However, the results of the study may be different for other majors. As a result, future studies should consider different majors for more robust and generalizable findings. Finally, other antecedents such as environmental concerns, moral norms, 
and responsibility can be combined to better understand pro-environmental intentions and behaviors.

Author Contributions: Conceptualization, S.K. and H.S.; methodology, S.K. and F.S.; software, S.K.; validation, S.K. and F.S.; formal analysis, S.K.; Investigation, F.S.; resources, S.K.; data curation, S.K. and H.S.; writing—original draft preparation, S.K., H.S. and G.L.; writing-review and editing, S.K., G.L. and F.S.; visualization, F.S.; supervision, S.K.; project administration, S.K. All authors have read and agreed to the published version of the manuscript.

Funding: The authors received no financial support for the research, authorship, and/or publication of this article.

Institutional Review Board Statement: Not applicable.

Informed Consent Statement: Not applicable.

Data Availability Statement: Not applicable.

Conflicts of Interest: The authors declare no conflict of interest.

\section{References}

1. Kumar, G.A. Framing a model for green buying behavior of Indian consumers: From the lenses of the theory of planned behavior. J. Clean. Prod. 2021, 295, 126487. [CrossRef]

2. Espeland, E.K.; Kettenring, K.M. Strategic plant choices can alleviate climate change impacts: A review. J. Environ. Manag. 2018, 222, 316-324. [CrossRef] [PubMed]

3. Liutsko, L. The integrative model of personality and the role of personality in a Planetary Health context. Personal. Individ. Differ. 2019, 151, 109512. [CrossRef]

4. 2020 Environmental Performance Index; Yale Center for Environmental Law \& Policy: New Haven, CT, USA. Available online: https: / / epi.yale.edu/ (accessed on 15 May 2021).

5. Karimi, S.; Saghaleini, A. Factors influencing ranchers' intentions to conserve rangelands through an extended theory of planned behavior. Glob. Ecol. Conserv. 2021, 26, e01513. [CrossRef]

6. Hashemzadeh, F. Environmental Awareness, Attitudes, and Behaviour of Secondary School Students and Teachers in Tehran, Iran. Ph.D. Thesis, The University of Waikato, Hamilton, New Zealand, 2016.

7. De Groot, J.I.M.; Steg, L. Value Orientations to Explain Beliefs Related to Environmental Significant Behavior. Environ. Behav. 2007, 40, 330-354. [CrossRef]

8. Kahan, D. The "Gateway Belief" illusion: Reanalyzing the results of a scientific-consensus messaging study. J. Sci. Commun. 2017, 16, A03. [CrossRef]

9. Thondhlana, G.; Hlatshwayo, T.N. Pro-Environmental Behaviour in Student Residences at Rhodes University, South Africa. Sustainability 2018, 10, 2746. [CrossRef]

10. Karimi, S. Pro-environmental behaviours among agricultural students: An examination of the value-belief-norm theory. J. Agric. Sci. Technol. 2019, 21, 249-263. [CrossRef]

11. Yu, T.-K. The Moderating Effects of Students' Personality Traits on Pro-Environmental Behavioral Intentions in Response to Climate Change. Int. J. Environ. Res. Public Health 2017, 14, 1472. [CrossRef]

12. Clayton, S.; Devine-Wright, P.; Swim, J.K.; Bonnes, M.; Steg, L.; Whitmarsh, L.; Carrico, A. Expanding the role for psychology in addressing environmental challenges. Am. Psychol. 2016, 71, 199-215. [CrossRef]

13. Asilsoy, B.; Oktay, D. Exploring environmental behaviour as the major determinant of ecological citizenship. Sustain. Cities Soc. 2018, 39, 765-771. [CrossRef]

14. Liu, P.; Teng, M.; Han, C. How does environmental knowledge translate into pro-environmental behaviors?: The mediating role of environmental attitudes and behavioral intentions. Sci. Total Environ. 2020, 728, 138126. [CrossRef]

15. Gkargkavouzi, A.; Halkos, G.; Matsiori, S. How do motives and knowledge relate to intention to perform environmental behavior? Assessing the mediating role of constraints. Ecol. Econ. 2019, 165. [CrossRef]

16. Bergek, A.; Mignon, I. Motives to adopt renewable electricity technologies: Evidence from Sweden. Energy Policy 2017, 106, 547-559. [CrossRef]

17. de Leeuw, A.; Valois, P.; Ajzen, I.; Schmidt, P. Using the theory of planned behavior to identify key beliefs underlying proenvironmental behavior in high-school students: Implications for educational interventions. J. Environ. Psychol. 2015, 42, 128-138. [CrossRef]

18. Vicente-Molina, M.; Fernández-Sainz, A.; Izagirre-Olaizola, J. Does gender make a difference in pro-environmental behavior? The case of the Basque Country University students. J. Clean. Prod. 2018, 176, 89-98. [CrossRef]

19. Alavi Moghaddam, M.; Maknoon, R.; Babazadeh Naseri, A.; Khanmohammadi Hazaveh, M.; Eftekhari Yegane, Y. Evaluation of Awareness, Attitude and Action of Amirkabir University of Technology Students on General Aspects of Environment. J. Environ. Sci. Technol. 2013, 14, 147-154. 
20. Marzban, A.; Barzegaran, M.; Hemayatkhah, M.; Ayasi, M.; Delavari, S.; Sabzehei, M.; Rahmanian, V. Evaluation of environmental awareness and behavior of citizens (case study: Yazd urban population). Iran. J. Health Environ. 2019, 12, 17-30.

21. Pouratashi, M.; Zamani, A. University students' level of knowledge, attitude and behavior toward sustainable development: A comparative study by GAMES. J. Appl. Res. High. Educ. 2021. [CrossRef]

22. Yadav, R.; Pathak, G.S. Determinants of Consumers' Green Purchase Behavior in a Developing Nation: Applying and Extending the Theory of Planned Behavior. Ecol. Econ. 2017, 134, 114-122. [CrossRef]

23. Liobikiene, G.; Mandravickaitè, J.; Bernatonienè, J. Theory of planned behavior approach to understand the green purchasing behavior in the EU: A cross-cultural study. Ecol. Econ. 2016, 125, 38-46. [CrossRef]

24. Ajzen, I. The theory of planned behavior. Organ. Behav. Hum. Decis. Process. 1991, 50, 179-211. [CrossRef]

25. Chan, L.; Bishop, B. A moral basis for recycling: Extending the theory of planned behaviour. J. Environ. Psychol. 2013, 36, 96-102. [CrossRef]

26. Maki, A.; Rothman, A.J. Understanding proenvironmental intentions and behaviors: The importance of considering both the behavior setting and the type of behavior. J. Soc. Psychol. 2016, 157, 517-531. [CrossRef] [PubMed]

27. Fielding, K.; McDonald, R.; Louis, W. Theory of planned behaviour, identity and intentions to engage in environmental activism. J. Environ. Psychol. 2008, 28, 318-326. [CrossRef]

28. Xu, X.; Hua, Y.; Wang, S.; Xu, G. Determinants of consumer's intention to purchase authentic green furniture. Resour. Conserv. Recycl. 2020, 156, 104721. [CrossRef]

29. Wang, Y.; Yang, J.; Liang, J.; Qiang, Y.; Fang, S.; Gao, M.; Fan, X.; Yang, G.; Zhang, B.; Feng, Y. Analysis of the environmental behavior of farmers for non-point source pollution control and management in a water source protection area in China. Sci. Total Environ. 2018, 633, 1126-1135. [CrossRef] [PubMed]

30. Si, H.; Shi, J.-G.; Tang, D.; Wu, G.; Lan, J. Understanding intention and behavior toward sustainable usage of bike sharing by extending the theory of planned behavior. Resour. Conserv. Recycl. 2020, 152, 104513. [CrossRef]

31. Perugini, M.; Bagozzi, R.P. The role of desires and anticipated emotions in goal-directed behaviours: Broadening and deepening the theory of planned behaviour. Br. J. Soc. Psychol. 2001, 40, 79-98. [CrossRef]

32. Wang, Y.; Liang, J.; Yang, J.; Ma, X.; Li, X.; Wu, J.; Yang, G.; Ren, G.; Feng, Y. Analysis of the environmental behavior of farmers for non-point source pollution control and management: An integration of the theory of planned behavior and the protection motivation theory. J. Environ. Manag. 2019, 237, 15-23. [CrossRef]

33. Liobikienè, G.; Poškus, M.S. The Importance of Environmental Knowledge for Private and Public Sphere Pro-Environmental Behavior: Modifying the Value-Belief-Norm Theory. Sustainability 2019, 11, 3324. [CrossRef]

34. Gifford, R.; Nilsson, A. Personal and social factors that influence pro-environmental concern and behaviour: A review. Int. J. Psychol. 2014, 49, 141-157. [CrossRef]

35. Corbett, J.B.; Durfee, J.L. Testing Public (Un)Certainty of Science. Sci. Commun. 2004, 26, 129-151. [CrossRef]

36. Ballew, M.T.; Omoto, A.M.; Winter, P. Using Web 2.0 and Social Media Technologies to Foster Proenvironmental Action. Sustainability 2015, 7, 10620-10648. [CrossRef]

37. Huang, H. Media use, environmental beliefs, self-efficacy, and pro-environmental behavior. J. Bus. Res. 2016, 69, $2206-2212$. [CrossRef]

38. Trivedi, R.H.; Patel, J.; Acharya, N. Causality analysis of media influence on environmental attitude, intention and behaviors leading to green purchasing. J. Clean. Prod. 2018, 196, 11-22. [CrossRef]

39. Zhang, X.; Zhong, Z.-J. Extending media system dependency theory to informational media use and environmentalism: A cross-national study. Telemat. Inform. 2020, 50, 101378. [CrossRef]

40. Ho, S.S.; Liao, Y.; Rosenthal, S. Applying the Theory of Planned Behavior and Media Dependency Theory: Predictors of Public Pro-environmental Behavioral Intentions in Singapore. Environ. Commun. 2014, 9, 77-99. [CrossRef]

41. Chin, H.-C.; Choong, W.-W.; Alwi, S.R.W.; Mohammed, A.H. Using Theory of Planned Behaviour to explore oil palm smallholder planters' intention to supply oil palm residues. J. Clean. Prod. 2016, 126, 428-439. [CrossRef]

42. Karimi, S.; Biemans, H.J.A.; Lans, T.; Mulder, M. Understanding the Role of Cultural Orientations in the Formation of Entrepreneurial Intentions in Iran. J. Career Dev. 2019. [CrossRef]

43. Overstreet, R.E.; Cegielski, C.; Hall, D. Predictors of the intent to adopt preventive innovations: A meta-analysis. J. Appl. Soc. Psychol. 2013, 43, 936-946. [CrossRef]

44. Greaves, M.; Zibarras, L.D.; Stride, C. Using the theory of planned behavior to explore environmental behavioral intentions in the workplace. J. Environ. Psychol. 2013, 34, 109-120. [CrossRef]

45. Aboelmaged, M. E-waste recycling behaviour: An integration of recycling habits into the theory of planned behaviour. J. Clean. Prod. 2021, 278, 124182. [CrossRef]

46. Kumar, A. Exploring young adults' e-waste recycling behaviour using an extended theory of planned behaviour model: A cross-cultural study. Resour. Conserv. Recycl. 2019, 141, 378-389. [CrossRef]

47. Cai, S.; Long, X.; Li, L.; Liang, H.; Wang, Q.; Ding, X. Determinants of intention and behavior of low carbon commuting through bicycle-sharing in China. J. Clean. Prod. 2019, 212, 602-609. [CrossRef]

48. Bandura, A. The Explanatory and Predictive Scope of Self-Efficacy Theory. J. Soc. Clin. Psychol. 1986, 4, 359-373. [CrossRef]

49. Li, J.; Zuo, J.; Cai, H.; Zillante, G. Construction waste reduction behavior of contractor employees: An extended theory of planned behavior model approach. J. Clean. Prod. 2018, 172, 1399-1408. [CrossRef] 
50. Fu, L.; Sun, Z.; Zha, L.; Liu, F.; He, L.; Sun, X.; Jing, X. Environmental awareness and pro-environmental behavior within China's road freight transportation industry: Moderating role of perceived policy effectiveness. J. Clean. Prod. 2020, $252,119796$. [CrossRef]

51. Sujata, M.; Khor, K.-S.; Ramayah, T.; Teoh, A.P. The role of social media on recycling behaviour. Sustain. Prod. Consum. 2019, 20, 365-374. [CrossRef]

52. Klöckner, C.A. A comprehensive model of the psychology of environmental behaviour-A meta-analysis. Glob. Environ. Chang. 2013, 23, 1028-1038. [CrossRef]

53. Yadav, R.; Pathak, G.S. Young consumers' intention towards buying green products in a developing nation: Extending the theory of planned behavior. J. Clean. Prod. 2016, 135, 732-739. [CrossRef]

54. Çoker, E.N.; Van Der Linden, S. Fleshing out the theory of planned of behavior: Meat consumption as an environmentally significant behavior. Curr. Psychol. 2020, 1-10. [CrossRef]

55. Yazdanpanah, M.; Forouzani, M. Application of the Theory of Planned Behaviour to predict Iranian students' intention to purchase organic food. J. Clean. Prod. 2015, 107, 342-352. [CrossRef]

56. Bamberg, S.; Möser, G. Twenty years after Hines, Hungerford, and Tomera: A new meta-analysis of psycho-social determinants of pro-environmental behaviour. J. Environ. Psychol. 2007, 27, 14-25. [CrossRef]

57. Hu, H.; Zhang, J.; Wang, C.; Yu, P.; Chu, G. What influences tourists' intention to participate in the Zero Litter Initiative in mountainous tourism areas: A case study of Huangshan National Park, China. Sci. Total Environ. 2019, 657, 1127-1137. [CrossRef]

58. Maichum, K.; Parichatnon, S.; Peng, K.C. Application of the extended theory of planned behavior model to investigate pur-chase intention of green products among Thai consumers. Sustainability 2016, 8, 1077. [CrossRef]

59. Pothitou, M.; Hanna, R.F.; Chalvatzis, K. Environmental knowledge, pro-environmental behaviour and energy savings in households: An empirical study. Appl. Energy 2016, 184, 1217-1229. [CrossRef]

60. Zsóka, N. Consistency and "awareness gaps" in the environmental behaviour of Hungarian companies. J. Clean. Prod. 2008, 16, 322-329. [CrossRef]

61. Zsóka, N.; Szerényi, Z.M.; Széchy, A.; Kocsis, T. Greening due to environmental education? Environmental knowledge, attitudes, consumer behavior and everyday pro-environmental activities of Hungarian high school and university students. J. Clean. Prod. 2013, 48, 126-138. [CrossRef]

62. Fryxell, G.E.; Lo, C.W.H. The Influence of Environmental Knowledge and Values on Managerial Behaviours on Behalf of the Environment: An Empirical Examination of Managers in China. J. Bus. Ethic 2003, 46, 45-69. [CrossRef]

63. Leonidou, L.; Leonidou, C.N.; Kvasova, O. Antecedents and outcomes of consumer environmentally friendly attitudes and behaviour. J. Mark. Manag. 2010, 26, 1319-1344. [CrossRef]

64. Vicente-Molina, M.A.; Fernandez-Sainz, A.; Izagirre-Olaizola, J. Environmental knowledge and other variables affecting proenvironmental behaviour: Comparison of university students from emerging and advanced countries. J. Clean. Prod. 2013, 61, 130-138. [CrossRef]

65. Liu, P.; Han, C.; Teng, M. The influence of Internet use on pro-environmental behaviors: An integrated theoretical framework. Resour. Conserv. Recycl. 2021, 164, 105162. [CrossRef]

66. Dodd, T.H.; Laverie, D.A.; Wilcox, J.F.; Duhan, D.F. Differential Effects of Experience, Subjective Knowledge, and Objective Knowledge on Sources of Information used in Consumer Wine Purchasing. J. Hosp. Tour. Res. 2005, 29, 3-19. [CrossRef]

67. Pagiaslis, A.; Krontalis, A.K. Green Consumption Behavior Antecedents: Environmental Concern, Knowledge, and Beliefs. Psychol. Mark. 2014, 31, 335-348. [CrossRef]

68. Ellen, P.S. Do we know what we need to know? Objective and subjective knowledge effects on pro-ecological behaviors. J. Bus. Res. 1994, 30, 43-52. [CrossRef]

69. Huang, Y.; Aguilar, F.; Yang, J.; Qin, Y.; Wen, Y. Predicting citizens' participatory behavior in urban green space governance: Application of the extended theory of planned behavior. Urban For. Urban Green. 2021, 61, 127110. [CrossRef]

70. McCombs, M.E.; Shaw, D.L. The Agenda-Setting Function of Mass Media. Public Opin. Q. 1972, 36, 176-187. [CrossRef]

71. Wen, N.; Chao, N.; Wang, C. Predicting the Intention of Sustainable Commuting among Chinese Commuters: The Role of Media and Morality. Environ. Commun. 2020, 15, 401-417. [CrossRef]

72. Carvalho, A. Media(ted)discourses and climate change: A focus on political subjectivity and (dis)engagement. Wiley Interdiscip. Rev. Clim. Chang. 2010, 1, 172-179. [CrossRef]

73. Höijer, B. Emotional anchoring and objectification in the media reporting on climate change. Public Underst. Sci. 2010, 19, 717-731. [CrossRef] [PubMed]

74. Masud, M.M.; Akhtar, R.; Afroz, R.; Al-Amin, A.Q.; Kari, F.B. Pro-environmental behavior and public understanding of climate change. Mitig. Adapt. Strat. Glob. Chang. 2013, 20, 591-600. [CrossRef]

75. Ahern, L. The Role of Media System Development in the Emergence of Postmaterialist Values and Environmental Concern: A Cross-National Analysis. Soc. Sci. Q. 2012, 93, 538-557. [CrossRef]

76. Lester, L.; Hutchins, B.; Lester, E. Power games: Environmental protest, news media and the internet. Media, Cult. Soc. 2009, 31, 579-595. [CrossRef]

77. Takahashi, B.; Tandoc, E.; Duan, R.; Van Witsen, A. Revisiting Environmental Citizenship. Environ. Behav. 2016, 49, 111-135. [CrossRef] 
78. Griffin, R.J.; Dunwoody, S.; Neuwirth, K. Proposed Model of the Relationship of Risk Information Seeking and Processing to the Development of Preventive Behaviors. Environ. Res. 1999, 80, S230-S245. [CrossRef] [PubMed]

79. Lee, K. The role of media exposure, social exposure and biospheric value orientation in the environmental attitude-intentionbehavior model in adolescents. J. Environ. Psychol. 2011, 31, 301-308. [CrossRef]

80. Zhao, X. Personal Values and Environmental Concern in China and the US: The Mediating Role of Informational Media Use. Commun. Monogr. 2012, 79, 137-159. [CrossRef]

81. Nelms, C.; Allen, M.W.; Craig, C.; Riggs, S. Who is the Adolescent Environmentalist? Environmental Attitudes, Identity, Media Usage and Communication Orientation. Environ. Commun. 2017, 11, 537-553. [CrossRef]

82. Coleman, C.-L. The Influence of Mass Media and Interpersonal Communication on Societal and Personal Risk Judgments. Commun. Res. 1993, 20, 611-628. [CrossRef]

83. Morton, T.A.; Duck, J.M. Communication and Health Beliefs. Commun. Res. 2001, 28, 602-626. [CrossRef]

84. Gong, X.; Zhang, J.; Zhang, H.; Cheng, M.; Wang, F.; Yu, N. Internet use encourages pro-environmental behavior: Evidence from China. J. Clean. Prod. 2020, 256, 120725. [CrossRef]

85. Lee, J.; Cho, M. The Effects of Consumers' Media Exposure, Attention, and Credibility on Pro-environmental Behaviors. J. Promot. Manag. 2019, 26, 434-455. [CrossRef]

86. Li, Z. Role of Affective Mediators in the Effects of Media Use on Pro-environmental Behavior. Sci. Commun. 2020, 43, 64-90. [CrossRef]

87. Liao, Y.; Ho, S.S.; Yang, X. Motivators of Pro-Environmental Behavior. Sci. Commun. 2015, 38, 51-73. [CrossRef]

88. Junsheng, H.; Akhtar, R.; Masud, M.M.; Rana, S.; Banna, H. The role of mass media in communicating climate science: An empirical evidence. J. Clean. Prod. 2019, 238. [CrossRef]

89. Holbert, R.L.; Kwak, N.; Shah, D.V. Environmental Concern, Patterns of Television Viewing, and Pro-Environmental Behaviors: Integrating Models of Media Consumption and Effects. J. Broadcast. Electron. Media 2003, 47, 177-196. [CrossRef]

90. Chan, K.K. Mass media and environmental knowledge of secondary school students in Hong Kong. Environmentalist 1998, 19, 85-97. [CrossRef]

91. Cheung, L.T.; Fok, L.; Tsang, E.P.; Fang, W.; Tsang, H. Understanding residents' environmental knowledge in a metropolitan city of Hong Kong, China. Environ. Educ. Res. 2014, 21, 507-524. [CrossRef]

92. Morgan, J. Geo-Graphing: Writing the World in Geography Classrooms; Institution of Education in London: London, UK, 1997.

93. Brothers, C.C.; Fortner, R.W.; Mayer, V.J. The Impact of Television News on Public Environmental Knowledge. J. Environ. Educ. 1991, 22, 22-29. [CrossRef]

94. Ostman, R.E.; Parker, J.L. A Public's Environmental Information Sources and Evaluations of Mass Media. J. Environ. Educ. 1987, 18, 9-17. [CrossRef]

95. Zhao, X. Media Use and Global Warming Perceptions. Commun. Res. 2009, 36, 698-723. [CrossRef]

96. Burton, R.J.; Riley, M. Traditional Ecological Knowledge from the internet? The case of hay meadows in Europe. Land Use Policy 2018, 70, 334-346. [CrossRef]

97. Karahan, E.; Roehrig, G. Constructing Media Artifacts in a Social Constructivist Environment to Enhance Students' Environmental Awareness and Activism. J. Sci. Educ. Technol. 2014, 24, 103-118. [CrossRef]

98. Zhang, L.; Kong, Y.; Chang, H. Media Use and Health Behavior in H1N1 Flu Crisis: The Mediating Role of Perceived Knowledge and Fear. Atl. J. Commun. 2015, 23, 67-80. [CrossRef]

99. Taufique, K.M.R.; Vaithianathan, S. A fresh look at understanding Green consumer behavior among young urban Indian consumers through the lens of Theory of Planned Behavior. J. Clean. Prod. 2018, 183, 46-55. [CrossRef]

100. Hamzah, M.I.; Tanwir, N.S. Do pro-environmental factors lead to purchase intention of hybrid vehicles? The moderating effects of environmental knowledge. J. Clean. Prod. 2021, 279, 123643. [CrossRef]

101. Hair, J.F.; Risher, J.; Sarstedt, M.; Ringle, C.M. When to use and how to report the results of PLS-SEM. Eur. Bus. Rev. 2019, 31, 2-24. [CrossRef]

102. Faul, F.; Erdfelder, E.; Buchner, A.; Lang, A.-G. Statistical power analyses using G*Power 3.1: Tests for correlation and regression analyses. Behav. Res. Methods 2009, 41, 1149-1160. [CrossRef]

103. Reinartz, W.; Haenlein, M.; Henseler, J. An empirical comparison of the efficacy of covariance-based and variance-based SEM. Int. J. Res. Mark. 2009, 26, 332-344. [CrossRef]

104. Han, H.; Hsu, L.-T.; Sheu, C. Application of the Theory of Planned Behavior to green hotel choice: Testing the effect of environmental friendly activities. Tour. Manag. 2010, 31, 325-334. [CrossRef]

105. Tan, C.-S.; Ooi, H.-Y.; Goh, Y.-N. A moral extension of the theory of planned behavior to predict consumers' purchase intention for energy-efficient household appliances in Malaysia. Energy Policy 2017, 107, 459-471. [CrossRef]

106. Ateş, H. Merging Theory of Planned Behavior and Value Identity Personal norm model to explain pro-environmental behaviors. Sustain. Prod. Consum. 2020, 24, 169-180. [CrossRef]

107. Markowitz, E.M.; Goldberg, L.R.; Ashton, M.C.; Lee, K. Profiling the "Pro-Environmental Individual": A Personality Perspective. J. Pers. 2011, 80, 81-111. [CrossRef]

108. Jagers, S.C.; Martinsson, J.; Matti, S. The Environmental Psychology of the Ecological Citizen: Comparing Competing Models of Pro-Environmental Behavior. Soc. Sci. Q. 2016, 97, 1005-1022. [CrossRef] 
109. Miao, L.; Wei, W. Consumers' Pro-Environmental Behavior and Its Determinants in the Lodging Segment. J. Hosp. Tour. Res. 2013, 40, 319-338. [CrossRef]

110. Kaiser, F.; Wilson, M.R. Goal-directed conservation behavior: The specific composition of a general performance. Pers. Individ. Differ. 2004, 36, 1531-1544. [CrossRef]

111. Mostafa, M.M. Gender differences in Egyptian consumers? green purchase behaviour: The effects of environmental knowledge, concern and attitude. Int. J. Consum. Stud. 2007, 31, 220-229. [CrossRef]

112. Denton, G.; Chi, O.H.; Gursoy, D. An examination of the gap between carbon offsetting attitudes and behaviors: Role of knowledge, credibility and trust. Int. J. Hosp. Manag. 2020, 90. [CrossRef]

113. Ringle, C.M.; Sarstedt, M.; Mitchell, R.; Gudergan, S. Partial least squares structural equation modeling in HRM research. Int. J. Hum. Resour. Manag. 2018, 31, 1617-1643. [CrossRef]

114. Ali, F.; Rasoolimanesh, S.M.; Sarstedt, M.; Ringle, C.M.; Ryu, K. An assessment of the use of partial least squares structural equation modeling (PLS-SEM) in hospitality research. Int. J. Contemp. Hosp. Manag. 2018, 30, 514-538. [CrossRef]

115. Chin, W.W. The Partial Least Squares Approach to Structural Equation Modeling; Erlbaum: Mahwah, NJ, USA, 1998; pp. 295-358.

116. Anderson, J.C.; Gerbing, D.W. Structural equation modeling in practice: A review and recommended two-step approach. Psychol. Bull. 1988, 103, 411-423. [CrossRef]

117. Henseler, J.; Ringle, C.M.; Sarstedt, M. A new criterion for assessing discriminant validity in variance-based structural equation modeling. J. Acad. Mark. Sci. 2014, 43, 115-135. [CrossRef]

118. Henseler, J.; Hubona, G.S.; Ray, P.A. Using PLS path modeling in new technology research: Updated guidelines. Ind. Manag. Data Syst. 2016, 116, 2-20. [CrossRef]

119. Cohen, J. Statistical Power Analysis for the Behavioral Sciences; Routledge: New York, NY, USA, 2013.

120. Zhao, X.; Lynch, J.; Chen, Q. Reconsidering Baron and Kenny: Myths and Truths about Mediation Analysis. J. Consum. Res. 2010, 37, 197-206. [CrossRef]

121. Alam, S.S.; Hashim, N.H.N.; Rashid, M.; Omar, N.A.; Ahsan, N.; Ismail, D. Small-scale households renewable energy usage intention: Theoretical development and empirical settings. Renew. Energy 2014, 68, 255-263. [CrossRef]

122. Aslam, W.; Farhat, K.; Arif, I. Regular to sustainable products: An account of environmentally concerned consumers in a developing economy. Int. J. Green Energy 2020, 18, 243-257. [CrossRef]

123. Barr, S.; Gilg, A.W.; Ford, N. The household energy gap: Examining the divide between habitual- and purchase-related conservation behaviours. Energy Policy 2005, 33, 1425-1444. [CrossRef]

124. Melville, N.P. Information Systems Innovation for Environmental Sustainability. MIS Q. 2010, 34. [CrossRef]

125. Alzubaidi, H.; Slade, E.L.; Dwivedi, Y.K. Examining antecedents of consumers' pro-environmental behaviours: TPB extended with materialism and innovativeness. J. Bus. Res. 2021, 122, 685-699. [CrossRef]

126. Karimi, S.; Saghaleini, A. What Drives Ranchers' Intention to Conserve Rangelands: The Role of Environmental Concern (A Case Study of Angoshteh Watershed in Borujerd County, Iran). J. Rangel. Sci. 2021. Available online: http://www.rangeland.ir/ article_681126.html (accessed on 22 March 2021).

127. Ohanian, R. Construction and Validation of a Scale to Measure Celebrity Endorsers' Perceived Expertise, Trustworthiness, and Attractiveness. J. Advert. 1990, 19, 39-52. [CrossRef]

128. Rutsaert, P.; Pieniak, Z.; Regan, A.; McConnon, A.; Kuttschreuter, M.M.M.M.; Lores, M.; Lozano-Monterrubio, N.; Guzzon, A.; Santare, D.; Verbeke, W. Social media as a useful tool in food risk and benefit communication? A strategic orientation approach. Food Policy 2014, 46, 84-93. [CrossRef]

129. Meyer, A. Does education increase pro-environmental behavior? Evidence from Europe. Ecol. Econ. 2015, 116, 108-121. [CrossRef]

130. Kaiser, F.; Schultz, P.W.; Berenguer, J.; Corral-Verdugo, V.; Tankha, G. Extending Planned Environmentalism. Eur. Psychol. 2008, 13, 288-297. [CrossRef]

131. Barber, N.N.; Taylor, C.J.; Strick, S.K. Wine consumers' environmental knowledge and attitudes: Influence on willingness to purchase. Int. J. Wine Res. 2009, 59. [CrossRef]

132. Onel, N.; Mukherjee, A. Consumer knowledge in pro-environmental behavior. World J. Sci. Technol. Sustain. Dev. 2016, 13, 328-352. [CrossRef] 